\title{
Asthma exacerbation by aspirin and chemical additives: use of a nucleotide template model to investigate potential mechanisms
}

\author{
Wynford R. Williams \\ Faculty of Life Sciences and Education, University of South Wales, Cardiff, United Kingdom
}

\begin{abstract}
Aspirin exacerbated asthma (AEA) affects approximately $10 \%$ of the asthmatic population. Clinical studies with a focus on abnormalities in arachidonate metabolism do not adequately account for susceptibility. Other pharmacological targets of aspirin receive less attention. Further investigation is required to elucidate mechanisms, improve on diagnosis and treatment. This study employs a molecular modeling approach, based on use of a nucleotide template, to standardise and compare molecular structures of compounds known to induce or prevent asthma. Results identify relative molecular similarity within the structures of drugs and cell mediators relevant to AEA and intolerance reactions. The investigated compounds provide equivalent fits to ligand structures for GABA, glycine, NMDA and nicotinic receptors. Chloride and ligand-gated ion channels are a common link between agents responsible for the induction and control of AEA. The methodology is applicable to compounds responsible for chemical-induced intolerance reactions.
\end{abstract}

Key words: Aspirin-induced asthma - Ion channels — Ligand-gated

\section{Introduction}

The properties of aspirin are duplicitous in nature. The drug is of importance for anti-platelet and anti-inflammatory action and of interest in limiting the development of some neoplasms but potentially damaging to the physiology of the stomach, skin, nasal and bronchial passages, auditory and angio-neural systems (Mastalerz et al. 2005; Kwok and Loke 2010; Sheppard et al. 2014; Stevens et al. 2015). Assessments of prophylactic aspirin use in the general population focus on major risks of increased mortality and neglect the considerable potential for increased morbidity (Thorat and Cuzick 2015). Both harmful and therapeutic effects are attributed to the inhibitory action of aspirin on cyclooxygenase, the enzyme responsible for prostaglandin synthesis (Nandakishore et al. 2014). Altered arachidonate metabolism by aspirin also leads to the production of aspirin triggered lipoxin with strong inhibitory effects on inflammatory signaling pathways and their cytokines (Wang et al. 2011). A better understanding of the mechanism of aspirin sensitivity in asthma patients, a condition characterized by chronic

Correspondence to: W. R. Williams, School of Care Sciences, University of South Wales, Cardiff CF37 1DL, United Kingdom E-mail: Robert.Williams2@southwales.ac.uk eosinophil inflammation and dysregulation of arachidonic acid metabolism, will facilitate development of a reliable in vitro test for better diagnosis of a potentially life-threatening condition (Velazquez and Teran 2013; Woessner 2017).

The molecular weight of aspirin is on a par with endogenous neurotransmitters and its chemical simplicity makes it multi-functional in regard to effects on enzymes, cell mediators and ion channels. In comparison to arachidonate metabolism, studies of salicylate action on ion channel function have received far less attention. Animal and in vitro studies demonstrate that aspirin and salicylate influence sodium, potassium, GABA , glycine and NMDA ion channels ( $\mathrm{Lu}$ et al. 2009). Hoang and co-authors (2010) are of the opinion that the primary defect in asthma is excitationbronchoconstriction resulting from the stimulation of cell membrane ion channels and receptors.

Research into the mechanism of AEA is aided by studies of adverse reactions in different organ systems, investigations of asthma-inducing agents that do not belong to the category of non steroidal anti-inflammatories (NSAIDs) and the therapeutic efficacy of unconventional anti-asthma drugs such as cromolyn and furosemide. Furosemide normalizes increased lung epithelial permeability, even in severe asthma, and is effective against a wide range of asthma provoking agents, including aspirin (Myers et al. 1997; Bhure et al. 2009). The 
similar asthma prophylactic spectrum of furosemide and cromolyn is attributable to their effects on chloride transport (Alton et al. 1996; Alton and Norris 1996).

The majority of therapeutic drugs target G-protein controlled receptors (GPCR) via a critical guanine nucleotide structure at the focus of the biochemical process controlling cell membrane signal transduction events (Johnston and Siderovski 2007). The anti-asthma drugs targeting GPCR include adrenoceptor agonists, anticholinergic agents and leukotriene antagonists (IUPHAR database (2017), www. guidetopharmacology.org). Purine nucleotides also feature prominently in the regulation of ligand- and voltage-gated ion channels, which are pharmacologic targets of chromones and salicylates (Alton and Norris 1996; Li et al. 2013). Molecular similarity within nucleotide and hormone structures targeting GPCR and ion channels is relevant to the abnormalities in cell-signal transduction processes associated with asthma. Guanine nucleotide has proven to be a useful reference structure for the standardization and comparison of drug and hormone structures by means of a computational chemistry program (Williams 2011). The methodology is applied here to the structures of compounds influencing aspirin intolerance and pseudo-allergic reactions, to determine if this approach assists in our understanding of the mechanisms responsible.

\section{Materials and Methods}

Molecular formulae of the investigated compounds are listed in IUPHAR (www.guidetopharmacology.org) and Pubchem (http://pubchem.ncbi.nlm.nih.gov) databases. The representative agonist and antagonist compounds selected for investigation and literature sources linking ligand structures to ion channel and cell mediator receptor targets are given in Table 1.

The building of molecular structures, and conformational analysis to obtain minimum energy conformers for use in superimposition and fitting studies, is undertaken with the Nemesis software program (Oxford Molecular version

Table 1. Reference sources and targets of compounds under investigation

\begin{tabular}{|c|c|c|c|c|c|c|c|c|}
\hline \multirow{3}{*}{ Compounds } & \multicolumn{5}{|c|}{ Ion channels } & \multicolumn{3}{|c|}{ Cell mediators } \\
\hline & \multicolumn{3}{|c|}{ chloride channels } & \multirow{2}{*}{ NMDA } & \multirow{2}{*}{ nAch } & \multirow{2}{*}{$\mathrm{Pg}$} & \multirow{2}{*}{$\mathrm{LT}$} & \multirow{2}{*}{ LXA4 } \\
\hline & $\mathrm{GABA}_{\mathrm{A}}$ & glycine & other & & & & & \\
\hline Furosemide & 1 & 1,9 & 11,12 & 20 & - & 25 & 29 & - \\
\hline Cromolyn & - & - & 11,13 & - & - & & 30 & - \\
\hline NPPB & 2 & - & 14,15 & - & - & 14 & 29 & - \\
\hline Niflumic acid & 1,2 & - & 2,16 & 2,20 & - & - & - & - \\
\hline Aspirin /salicylate & 3 & 10 & - & 21 & - & 26 & 31 & - \\
\hline Prostaglandin E2 (PgE2) & 4 & - & 17 & - & - & - & 32 & - \\
\hline Isoguvacine & 5 & - & - & - & - & - & - & - \\
\hline U93631 & 6 & - & - & - & - & - & - & - \\
\hline Bicuculline & 5 & 7 & - & - & - & - & - & - \\
\hline Strychnine & 7 & 7 & - & - & - & - & - & - \\
\hline Toluene-diisocyanate (TDI) & 8 & - & - & - & 8 & - & - & - \\
\hline Leukotriene E4 (LTE4) & - & - & 18 & 22 & - & 27 & - & - \\
\hline Lipoxin A4 (LXA4) & - & - & 19 & - & - & 28 & - & - \\
\hline N-methyl-D-aspartate (NMDA) & - & - & - & 23 & - & - & - & - \\
\hline Quinolinic acid & - & - & - & 23 & - & - & - & - \\
\hline MK801 & - & - & - & 23 & - & - & - & - \\
\hline Nicotine & - & - & - & - & 8 & - & - & - \\
\hline Epibatidine & - & - & - & - & 8 & - & - & - \\
\hline Aspartame & - & - & - & 24 & - & - & - & - \\
\hline Montelukast & - & - & - & - & - & - & - & 33 \\
\hline
\end{tabular}

1, Kumamoto and Murata 1997; 2, Zhao et al. 2016; 3, Gong et al. 2008; 4, Kimura et al. 1985; 5, Allan \& Harris 1986; 6, Dillon et al. 1995; 7, Shirasaki et al. 1991; 8, Liu et al. 2006; 9, Dudeck et al. 2003; 10, Lu et al. 2009; 11, Alton et al. 1996; 12, Deisz et al. 2011; 13, Reinsprecht et al. 1992; 14, Breuer and Skorecki 1989; 15, Babot et al. 2005; 16, Liantonio et al. 2007; 17, Moeser et al. 2004; 18, Jett et al. 1991; 19, Verriere et al. 2012; 20, Lerma and Martin del Rio 1992; 21, Deng et al. 2013; 22, Kiyoyuki et al. 2015; 23, Pawley et al. 1996; 24, Abdollahi et al. 2001; 25, Pavord et al. 1995; 26, Nandakishore et al. 2014; 27, Salimi et al. 2017; 28, Kumar et al. 2014; 29, Perkins et al. 1992; 30, Yoshida et al. 1998; 31, Planaguma et al. 2002; 32, Narayanankutty et al. 2013; 33, Cai et al. 2007. 
2.1). All ligand structures are minimum energy conformers in an uncharged form. The low energy conformer of GTP nucleotide is from a previous setting (Williams 2011). The program fits paired molecular structures on a 3 point basis. Fitting points comprise of selected atom pairs of similar type and partial charge within ligand and nucleotide structures. The sequence of fitting to the nucleotide is given for each compound in Table 2 (reading from left to right). The Nemesis program computes goodness-of-fit values, in respect of inter-atomic distance at each fitting point and the root mean square value. Ligand fitting points are identified in the Figures by colour-coded atoms: carbon-green, nitrogen-blue, oxygen-red. Bond order within molecular structures is not shown and the nucleotide structure is cropped to improve on presentation

Table 2. Fitting data for ligands superimposed on the GTP template

\begin{tabular}{|c|c|c|c|}
\hline Compounds & Fitting points & $\begin{array}{l}\text { Inter-atomic } \\
\text { distance }(\AA)\end{array}$ & $\begin{array}{c}\text { RMS } \\
(\AA)\end{array}$ \\
\hline Acetylcholine & N9C4C5 & $0.19,0.02,0.20$ & 0.0277 \\
\hline Aspartame & O6C6C5 & $0.09,0.05,0.08$ & 0.0034 \\
\hline Aspirin & $\mathrm{C} 6 \mathrm{C} 5 \mathrm{C} 4$ & $0.04,0.00,0.04$ & 0.0041 \\
\hline Bicuculline & C4C5C6 & $0.01,0.03,0.01$ & 0.0014 \\
\hline Cromolyn & O6C6C1' & $0.10,0.12,0.08$ & 0.0113 \\
\hline Epibatidine & C6C5C1' & $0.06,0.01,0.07$ & 0.0010 \\
\hline Furosemide & O6C6C5 & $0.07,0.03,0.04$ & 0.0039 \\
\hline Furosemide & O6C6N1 & $0.09,0.02,0.08$ & 0.0031 \\
\hline Furosemide & $\mathrm{C} 6 \mathrm{C} 5 \mathrm{C} 4$ & $0.02,0.01,0.01$ & 0.0019 \\
\hline GABA & C4C5C6 & $0.09,0.10,0.06$ & 0.0156 \\
\hline Glycine & O6C6N1 & $0.02,0.06,0.08$ & 0.0059 \\
\hline Isoguvacine & C4C5C6 & $0.01,0.02,0.02$ & 0.0014 \\
\hline Lipoxin A4 & $\mathrm{C} 5 \mathrm{C} 4 \mathrm{O} 2$ & $0.05,0.06,0.02$ & 0.0084 \\
\hline LTE4 & O6C6C5 & $0.01,0.04,0.05$ & 0.0042 \\
\hline LTE4 & C8N9C1' & $0.07,0.13,0.06$ & 0.0328 \\
\hline MK801 & N9C4C6 & $0.11,0.06,0.05$ & 0.0014 \\
\hline Montelukast & C8N9C1' & $0.08,0.14,0.06$ & 0.0337 \\
\hline Nicotine & N9C4C5 & $0.13,0.04,0.14$ & 0.0052 \\
\hline Niflumic acid & $\mathrm{C} 6 \mathrm{C} 5 \mathrm{C} 4$ & $0.02,0.01,0.03$ & 0.0012 \\
\hline Niflumic acid & O6C6C5 & $0.07,0.03,0.04$ & 0.0036 \\
\hline NMDA & O6C6C5 & $0.09,0.03,0.09$ & 0.0014 \\
\hline NPPB & C4C5C6 & $0.02,0.02,0.02$ & 0.0025 \\
\hline Prostaglandin E2 & C4C5C6 & $0.08,0.11,0.06$ & 0.0212 \\
\hline Prostaglandin E2 & $\mathrm{C} 5 \mathrm{C} 4 \mathrm{C} 8$ & $0.09,0.10,0.11$ & 0.0006 \\
\hline Quinolinic acid & O6C6C5 & $0.07,0.03,0.05$ & 0.0022 \\
\hline Salicylate & O6C6N1 & $0.03,0.03,0.06$ & 0.0014 \\
\hline Strychnine & O6C6N1 & $0.01,0.01,0.02$ & 0.0010 \\
\hline TDI & C6C5C1' & $0.07,0.07,0.04$ & 0.0134 \\
\hline U93631 & C4C5C6 & $0.09,0.07,0.09$ & 0.0286 \\
\hline
\end{tabular}

LTE4, leukotriene E4; NMDA, N-methyl-D-aspartate; TDI, toluene-diisocyanate; NPPB, 5-nitro-2-(3-phenylpropylamino) benzoic acid.

\section{Results}

Results of the molecular modeling study are presented for ligand-gated ion channel (LGIC) ligands, and compounds modulating asthma and chemical-induced adverse reactions. Goodness-of-fit for the structures in Figures 1-3 does not exceed $0.20 \AA$ and $0.0300 \AA$ for inter-atomic distance and root mean square value, respectively (Table 2 ).

Compounds with a regulatory action on LGIC relate to several fitting patterns on the GTP template (Figure 1). The agonist and antagonist structures are ligands at $\mathrm{GABA}_{\mathrm{A}}$, glycine, NMDA and nicotinic (nAch) receptors; bicuculline is active at glycine and $\mathrm{GABA}_{\mathrm{A}}$ receptors. $\mathrm{GABA}_{\mathrm{A}}$ and nAch ligands fit at the nucleotide endocyclic C4-C5 bond with the third fitting point at C6 (GABA) or N9 (nAch). The
B

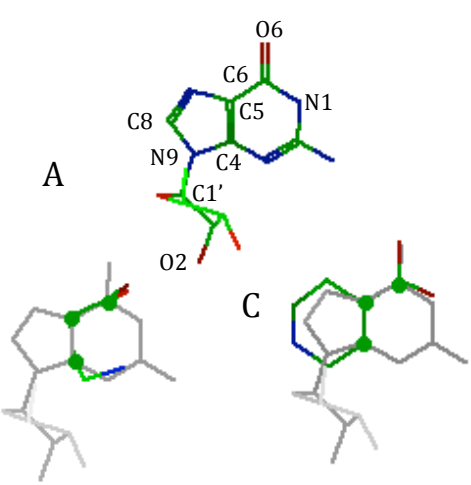

E
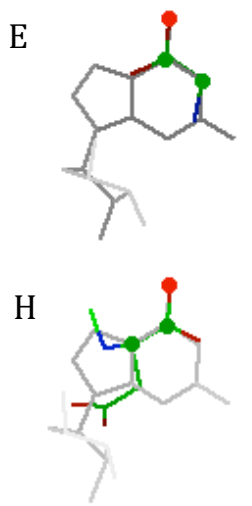

$\mathrm{K}$

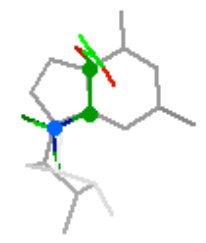

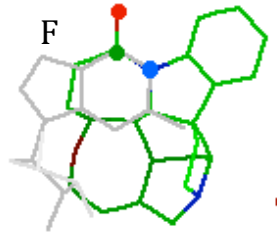
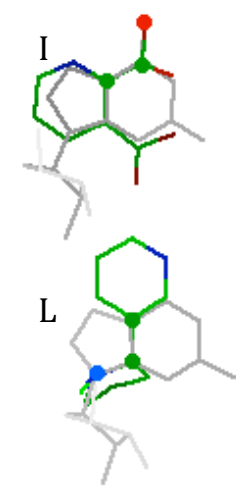
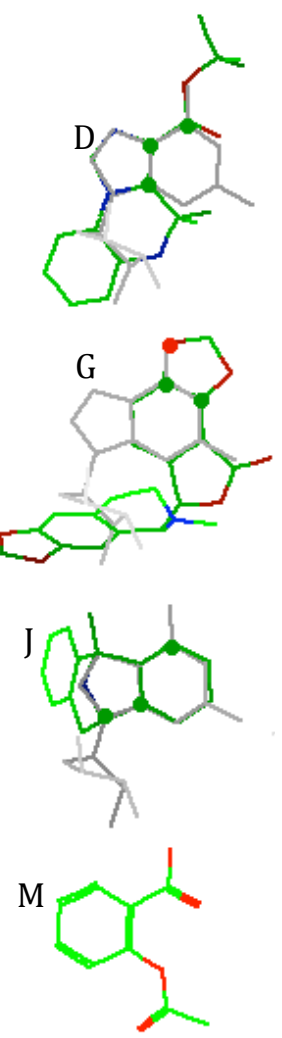

Figure 1. Fits of ligand-gated ion channel ligands to guanine nucleotide (A) templates (grey): GABA (B), isoguvacine (C), U93631 (D), glycine (E), strychnine (F), bicuculline (G), NMDA $(\mathbf{H})$, quinolinic acid (I), MK801 (J), acetylcholine (K), nicotine (L), aspirin (M). Agonist structures: B, C, E, H, I, K, L; antagonist structures: D, F, G, J. 


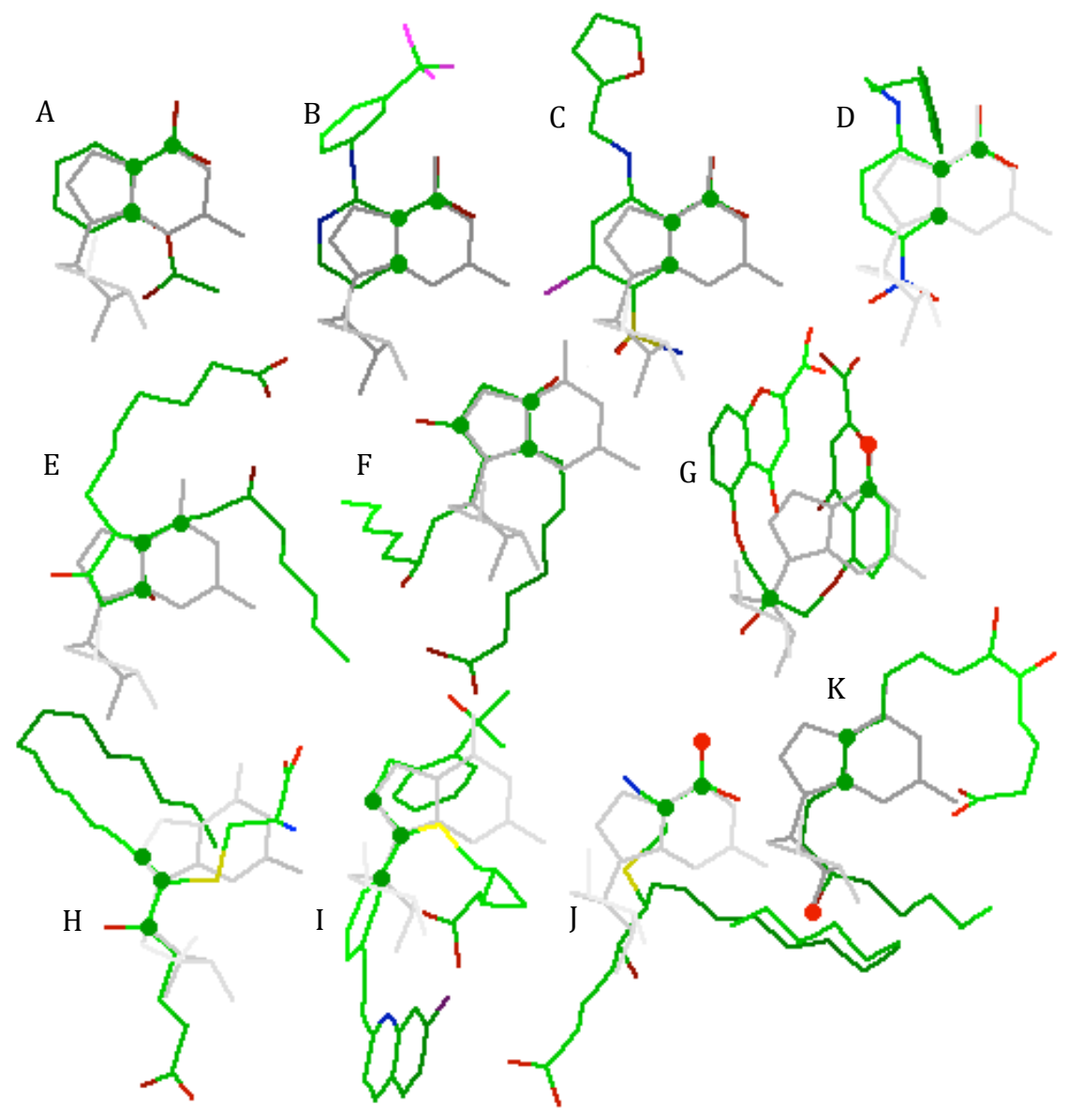

Figure 2. Fits of asthma modulating agents to guanine nucleotide templates (grey): aspirin (A), niflumic acid (B), furosemide (C), NPPB (D), PGE2 (E), PGE2 (F), cromolyn (G), LTE4 (H), montelukast (I), LTE4 (J), LXA4 (K). fits of glycine and NMDA ligands focus on the C6 carbonyl group of the guanine ring. Aspirin structure $(\mathrm{M})$ is markedly similar to the $\mathrm{GABA}_{\mathrm{A}}$ agonist isoguvacine (C) and NMDA agonist quinolinic acid (I). The N9C4C5 fitting values of acetylcholine and nicotine, also replicated by minimum energy conformers of the agonists carbamoylcholine, RJR2429 and SIB1508Y (data not shown), are amongst the weakest of the LGIC ligands (Table 2).

Structures A-E, in Figure 2, provide a $\mathrm{GABA}_{\mathrm{A}}$-like fit (C6C5C4) to the nucleotide template. Fitting values for structures $\mathrm{B}, \mathrm{C}$ and $\mathrm{D}$, chloride channel inhibitors with preventative effects on AEA, are better than the fit of GABA (Table 2). In comparison to the structure of aspirin (A), fitted chloride channel inhibitors present inhibitory alkyl chains and cyclic rings above the guanine ring in common with PgE2 (E) and cromolyn (G). The structures of cromolyn, LXA4 (K), LTE4 $(\mathrm{H})$ and the LTE4 antagonist montelukast (I) have a fitting point on the ribose moiety of GTP at O2 or C1'. Structure J (LTE4) replicates the fit of NMDA in Figure 1 (the terminus of the side-chain of LTE4 comprises of a glutamate residue) with better fitting values than the alternative fit, template $\mathrm{H}$. Template F provides an alternative to the $\mathrm{GABA}_{\mathrm{A}}$ fit of PgE2.
Figure 3 gives the glycine-like fits of furosemide (A) and salicylate (B) and the NMDA-like fits of furosemide (C), niflumic acid (D) and aspartame (E). Differences between antagonist (C and D) and exacerbator (E) action at the NMDA receptor are evident in the positioning of a nonfitting cyclic ring, which is absent in aspartame and NMDA (Figure 1) exacerbator structures. TDI (F) and the nicotinic ligand epibatidine $(\mathrm{G})$ use the same fitting points on the GTP template but differ in the superimposition of a cyclic ring on the aminouracil moiety of the nucleotide.

\section{Discussion}

The nucleotide template model facilitates the recognition of molecular similarity within the structures of compounds with established roles in the exacerbation and amelioration of asthma. In regard to ligand-gated ion channels, aspirin and salicylate provide NMDA-, GABA- and glycine-like fits to the nucleotide that relate to functionality at these receptors. Aspirin potentiates NMDA responses in ganglionic neuron cultures (Peng et al. 2003). Salicylate is equipotent at 


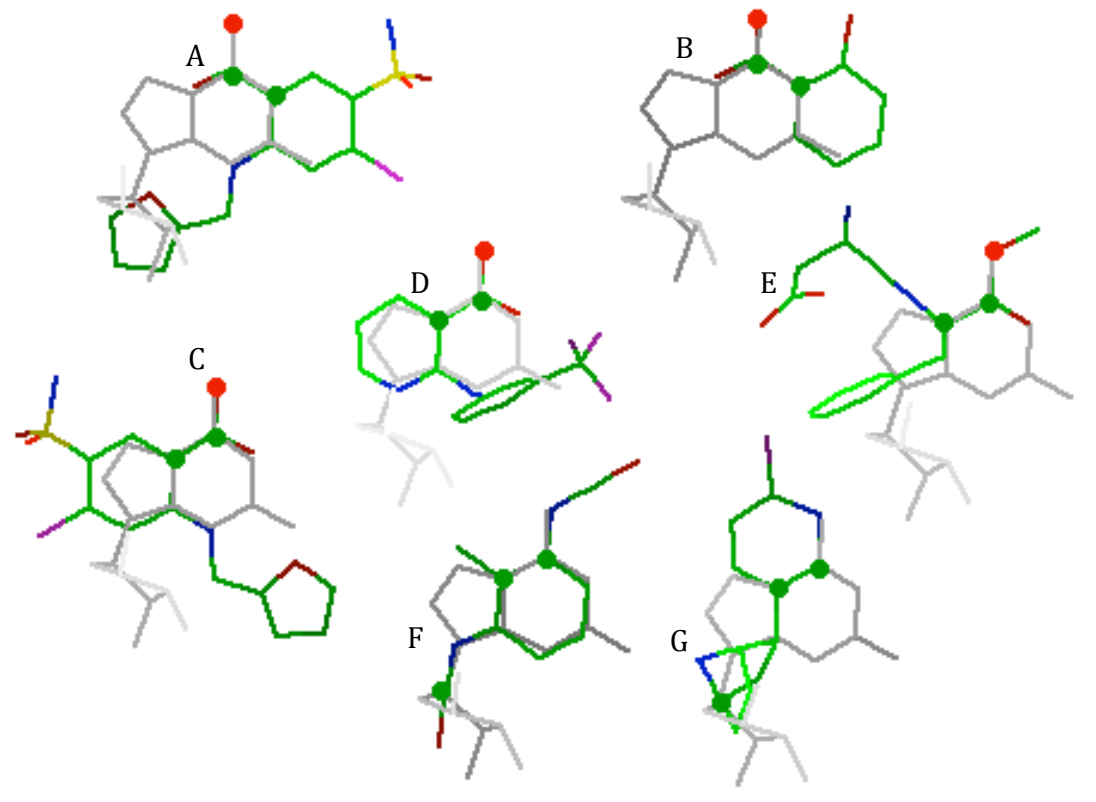

Figure 3. Fits of intolerance-inducing agents and antagonists to guanine nucleotide templates (grey): furosemide (A), salicylate (B), furosemide (C), niflumic acid (D), aspartame (E), toluene diisocyanate (F), epibatidine (G).
$\mathrm{GABA}_{\mathrm{A}}$ and glycine receptors, inhibiting responses in neuron cultures from spinal dorsal horn and hippocampal slices, respectively (Gong et al. 2008; Lu et al. 2009). Salicylate has a pre-synaptic stimulatory effect on rat medullary inspiratory neurons, whereas a higher inhibitory concentration is antagonised by bicuculline, a GABA antagonist (Akada et al. 2003). GABA transmission is not confined to the central nervous system and release of the neurotransmitter from epithelial cells contributes to airway smooth muscle relaxation and regulation of mucous production (Danielsson et al. 2016). Glycine, calcium-activated chloride and Na-Kchloride co-transporter channels are also important in maintaining airways smooth muscle relaxation (Danielsson et al. 2014).

The structures of asthma ameliorating compounds such as cromolyn, PgE2 and furosemide use the same template fitting points as aspirin but reveal additional complexity in their fit to the nucleotide. These anti-asthma compounds influence chloride channel sites and demonstrate interaction in vitro. Furosemide and cromolyn attenuate challenge tests on asthmatic subjects and block conductance of a voltage- and calcium-dependent chloride channel in airways epithelium (Alton et al. 1996; Myers et al. 1997). Niflumic acid, a COX-2 inhibitor, targets the same inhibitory receptor site as furosemide at $\mathrm{GABA}_{\mathrm{A}}$ receptors (Zhao et al. 2016). Niflumic acid, NPPB and furosemide block chloride conductance, in airway epithelium, initiated by E-ring isoprostanes (Seto et al. 2008). Prostaglandins promote the action of GABA but their effects are also subject to regulation by ligands binding to the $\mathrm{GABA}_{\mathrm{A}}$ receptor (Kimura et al. 1985; Nonogaki et al. 1993). Furosemide and NSAIDs both target specific sub-units of the GABA receptor (Korpi et al. 2002; Sinkkonen et al. 2003).

The drugs under investigation are pluripotent in terms of receptor binding (see Table 1) and this is reflected in different receptor type fits to the guanine nucleotide template. Enhancement of the NMDA current by aspirin and salicylate is linked to the development of tinnitus and ganglionic cell death (Peng et al. 2003; Deng et al. 2013). Furosemide prevents NMDA receptor activation and inhibits the strychnine sensitive glycine receptor in cultured spinal cord neurons (Lerma and Martin del Rio 1992; Dudeck et al. 2003). Leukotrienes promote NMDA activity in neurons of the rat spinal cord (Kiyoyuki et al. 2015). There is experimental evidence for the participation of NMDA receptors in airway hyperreactivity but no established link between leukotrienes and NMDA receptors in airway inflammation (Antosova and Strapkova 2013; Anaparti et al. 2015).

Aspartame and TDI have records of long term controversial use in food and manufacturing processes. Aspartame causes neurological disturbances, activating the NMDA receptor and NO-cGMP pathway in mice (Abdollahi et al. 2001). The aspartame structure provides a NMDA-like fit to the nucleotide template. TDI has a considerable reputation for causing health problems, including asthma, in the work environment. In vitro studies demonstrate suppression and partial suppression of nicotinic and GABA receptor responses, respectively (Liu et al. 2006). TDI provides a similar nucleotide template fit to the nicotinic ligand epibatidine and is known to suppress a $\mathrm{Ca}^{2+}$ current promoted by epibatidine in human neuroblastoma cells (Liu et al. 2006). Other irritant sensitising agents of interest in the occupational health 
setting are organic acid anhydrides, which are structural analogues of aspirin with anti-inflammatory properties and inhibitory effects on prostaglandin synthesis (Killackey et al. 1984; Teng et al. 1987).

The multiple properties and concentration dependent effects of aspirin on cell targets contribute to the difficulty of establishing a mechanism for AEA. Aspirin targeting of neurotransmitter receptors may also provide opposing actions under different conditions. The global inhibitory action of GABA may change under depolarising conditions to contribute to glutamate excitotoxicity (Babot et al. 2005). Aspirin also influences the balance of cell mediators derived from the arachidonic cascade within the chemical milieu of inflammation. A singular focus on reciprocal changes in prostaglandin and leukotriene levels in AEA, therefore, inadequately addresses the action of aspirin in exacerbating asthma. Of the cell receptors implicated in AEA, chloride ion channels and NMDA receptors are common targets of aspirin, inflammatory mediators and the drugs providing protection.

In conclusion, molecular modelling methodology based on the use of a purine nucleotide template is a useful approach to the comparative study of asthma-inducing agents and anti-asthma drugs in respect of structure-activity data. Literatures sources and molecular fitting data indicate that activated NMDA and chloride channels contribute to AEA and the condition does not result from protein targets entirely concerned with arachidonate metabolism.

Conflict of interest. I declare that there is no conflict of interest within the content of the manuscript. There are no sources of funding or sponsors associated with this work.

\section{References}

Abdollahi M, Nikfar S, Abdoli N (2001): Potentiation by nitric oxide synthetase inhibitor and calcium channel blocker of aspartameinduced antinociception in the mouse formalin test. Fundam. Clin. Pharmacol. 15, 117-123

https://doi.org/10.1046/j.1472-8206.2001.00013.x

Akada S, Takeda S, Ogawa R (2003): Salicylate action on medullary inspirational neuron activity in a brainstem-spinal cord preparation from newborn rats. Anesth. Analg. 96, 407-411

Allan AM, Harris RA (1986): gamma-Aminobutyric acid agonists and antagonists alter chloride flux across brain membranes. Mol. Pharmacol. 29, 497-505

Alton EW, Kingsleigh-Smith DJ, Munkonge FM, Smith SN, Lindsay AR, Gruenert DC, Jeffrey PK, Norris A, Geddes DM, Williams AJ (1996): Asthma prophylaxis agents alter the function of an airway epithelial chloride channel. Am. J. Resp. Cell Mol. Biol. 14, 380-387 https://doi.org/10.1165/ajrcmb.14.4.8600943

Alton EWFW, Norris AA (1996): Chloride transport and the actions of nedocromil sodium and cromolyn sodium in asthma. J. Allergy Clin. Immunol. 98, S102-S110
https://doi.org/10.1016/S0091-6749(96)70024-6

Anaparti V, Ilarraza R, Orihara K, Stelmack GL, Oluwaseun OO, Mahood TH, Unruh H, Halayko AJ, Moqbel R (2015): NMDA receptors mediate contractile responses in human airway smooth muscle cells. Am. J. Physiol. Lung Cell Mol. Physiol. 308, L1253-L1264

https://doi.org/10.1152/ajplung.00402.2014

Antosova M, Strapkova A (2013): Study of the interaction of glutamatergic and nitrergic signalling in conditions of the experimental airways hyperreactivity. Pharmacol. Rep. 65, 650-657 https://doi.org/10.1016/S1734-1140(13)71042-9

Babot Z, Cristofol R, Sunol C (2005): Excitotoxic death induced by released glutamate in depolarized primary cultures of mouse cerebellar granule cells is dependent on GABAA receptors and niflumic acid-sensitive chloride channels. Eur. J. Neurosci. 21, 103-112

https://doi.org/10.1111/j.1460-9568.2004.03848.x

Bhure UN, Bhure S, Bhatt BM, Mistry S, Pednekar SJ, Chari W, Desai SA, Joshi JM, Paidhungat AJ (2009): Lung epithelial permeability and inhaled furosemide: added dimensions in asthmatics. Ann Nucl Med 23, 549-557

https://doi.org/10.1007/s12149-009-0275-z

Breuer W, Skorecki KL (1989): Inhibition of prostaglandin E2 synthesis by a blocker of epithelial chloride channels. Biochem. Biophys. Res. Commun. 163, 398-405 https://doi.org/10.1016/0006-291X(89)92149-9

Cai C, Yang J, Hu S, Zhou M, Guo W (2007): Relationship between urinary cysteininyl leukotriene E4 levels and clinical response to antileukotriene treatment in patients with asthma. Lung 185, 105-112 https://doi.org/10.1007/s00408-006-0001-8

Danielsson J, Yim P, Rinderspacher A, Fu XW, Zhang Y, Landry DW, Emala CW (2014): Chloride channel blockade relaxes airway smooth muscle and potentiates relaxation by $\beta$-agonists. Am. J. Physiol. Lung Cell Mol. Physiol. 307, L273-L282 https://doi.org/10.1152/ajplung.00351.2013

Danielsson J, Zaidi S, Kim B, Yim PD, Xu D, Worgall TS, Gallos G, Emala CW (2016): Airway epithelial cell release of GABA is regulated by protein kinase A. Lung 194, 401-408 https://doi.org/10.1007/s00408-016-9867-2

Deisz RA, Lehmann TN, Horn P, Dehnicke C, Nitsch R (2011): Components of neuronal chloride transport in rat and human neocortex. J. Physiol. 589, 1317-1347 https://doi.org/10.1113/jphysiol.2010.201830

Deng L, Ding D, Su J, Manohar S, Salvi R (2013): Salicylate selectively kills cochlear spiral ganglionic neurons by paradoxically up-regulating superoxide. Neurotox. Res. 24, 307-319 https://doi.org/10.1007/s12640-013-9384-5

Dillon GH, Im WB, Pregenzer JF, Carter DB. Hamilton BJ (1995): [4-Dimethyl-3-t-butylcarboxyl-4,5-dihydro (1,5-a) quinoxaline] is a novel ligand to the picrotoxin site on GABAA receptors, and decreases single-channel open probability. J. Pharmacol. Exp. Ther. 272, 597-603

Dudeck O, Lubben S, Eipper S, Knorle R, Kirsch M, Honegger J, Zentner J, Feuerstein TJ (2003): Evidence for strychninesensitive glycine receptors in human amygdala. Naunyn Schmeidebergs Arch. Pharmacol. 368, 181-187 https://doi.org/10.1007/s00210-003-0786-4 
Gong N, Zhang M, Zhang XB, Chen L, Sun GC, Xu TL (2008): The aspirin metabolite salicylate enhances neuronal excitation in rat hippocampal CA1 area through reducing GABAergic inhibition. Neuropharmacology 54, 454-463 https://doi.org/10.1016/j.neuropharm.2007.10.017

Hoang BX, Shaw DG, Pham P, Levine SA (2010): Treating asthma as a neuroelectrical disorder. Inflamm. Allergy Drug Targets 9, 130-134 https://doi.org/10.2174/187152810791292827

Jett MF, Marshall P, Fondacaro JD, Smith P (1991): Action of peptidoleukotrienes on ion transport in rat distal colon in vitro. J. Pharmacol. Exp. Ther. 257, 698-705

Johnston CA. Siderovski DP (2007): Receptor-mediated activation of heterotrimeric G-proteins: current structural insights. Mol. Pharmacol. 72, 219-230 https://doi.org/10.1124/mol.107.034348

Killackey JJ, Killackey BA, Cerskus I, Philp RB (1984): Antiinflammatory properties of a hydroxyperoxide compound, structurally related to acetylsalicylic acid. Inflammation 8, 157-169 https://doi.org/10.1007/BF00916091

Kimura H, Okamoto K, Sakai Y (1985): Modulatory effects of prostaglandin D2, E2 and F2 alpha on the postsynaptic actions of inhibitory and excitatory amino acids in cerebellar Purkinje cell dendrites in vitro. Brain Res. 330, 235-244 https://doi.org/10.1016/0006-8993(85)90682-1

Kiyoyuki Y, Taniguchi W, Okubo M, Yamanaka H, Kobayashi K, Nishio N, Nakatsuka T, Noguchi K (2015): Leukotriene enhances NMDA-induced inward currents in dorsal horn neurons of the rat spinal cord after peripheral nerve injury. Mol. Pain 11, 53 https://doi.org/10.1186/s12990-015-0059-5

Korpi ER, Grunder G, Luddens H (2002): Drug interactions at GABAA receptors. Prog. Neurobiol. 67, 113-159 https://doi.org/10.1016/S0301-0082(02)00013-8

Kumar R, Clerc AC, Gori I, Russel R, Pellegrini C, Govender L, Wyss JC, Golshayan D, Canny GO (2014): Lipoxin A4 prevents the progression of de novo and established endometriosis in a mouse model by attenuating prostaglandin E2 production and estrogen signalling. PLoS One 9, 2 https://doi.org/10.1371/journal.pone.0089742

Kumamoto E, Murata Y (1997): Action of furosemide on GABAand glycine currents in rat septal cholinergic neurons in culture. Brain Res. 776, 246-249

https://doi.org/10.1016/S0006-8993(97)01083-4

Kwok CS, Loke YK (2010): Critical overview on the benefits and harms of aspirin. Pharmaceuticals 3, 1491-1506 https://doi.org/10.3390/ph3051491

Lerma J, Martin del Rio R (1992): Chloride transport blockers prevent N-methyl-D-aspartate receptor-channel complex activation. Mol. Pharmacol. 41, 217-222

Li Y, Gao J, Lu Z, McFarland K, Shi J, Bock K, Cohen IS, Cui J (2013): Intracellular ATP binding is required to activate the slowly activating K+ channel IKS. Pro. Natl. Acad. Sci. USA 110, 18924-18927 https://doi.org/10.1073/pnas.1315649110

Liantonio A, Giannuzzi V, Picollo A, Babini E, Pusch M, Camerino DC (2007): Niflumic acid inhibits chloride conductance of rat skeletal muscle by directly inhibiting the CLC-1 channel and by increasing intracellular calcium. Br. J. Pharmacol. 150, 235-247 https://doi.org/10.1038/sj.bjp.0706954

Liu PS, Chiung YM, Kao YY, Chen HT (2006): 2,4-Toluene diisocynate suppressed the calcium signaling of ligand gated ion channel receptors. Toxicology 219, 167-174 https://doi.org/10.1016/j.tox.2005.11.012

Lu YG, Tang ZQ, Ye ZY, Wang HT, Huang YN, Zhou KQ, Zhang $\mathrm{M}, \mathrm{Xu}$ TL, Chen L (2009): Salicylate, an aspirin metabolite, specifically inhibits the current mediated by glycine receptors containing a1-subunts. Brit. J. Pharmacol. 157, 1514-1522 https://doi.org/10.1111/j.1476-5381.2009.00321.x

Mastalerz L, Setkowicz M, Szczeklik A (2005): Mechanism of chronic urticarial exacerbation by aspirin. Curr. Allergy Asthma Rep. 5, 277-283 https://doi.org/10.1007/s11882-005-0067-z

Moeser A.J, Haskell MM, Shifflett DE, Little D, Schultz BD, Blikslager AT (2004): CLC-2 chloride secretion mediates prostaglandin-induced recovery of barrier function in iscahemia-injured porcine ileum. Gastroenterology 127, 802-815 https://doi.org/10.1053/j.gastro.2004.06.004

Myers JD, Higham MA, Shakur BH, Wickremasinghe PW (1997): Attenuation of propranolol-induced bronchoconstriction by frusemide. Thorax 52, 861-865 https://doi.org/10.1136/thx.52.10.861

Nandakishore R, Yalavarthi PR, Kiran YR, Rajapranathi M (2014): Selective cyclooxygenase inhibitors: current status. Curr. Drug Discov. Technol. 11, 127-132 https://doi.org/10.2174/1570163811666140127123717

Narayanankutty A, Resendiz-Hernandez JM, Falfan-Valencia R, Teran LM (2013): Biochemical pathogenesis of aspirin exacerbated respiratory disease (AERD). Clin. Biochem. 4, 566-578 https://doi.org/10.1016/j.clinbiochem.2012.12.005

Nonogaki K, Mizuno S, Tamagawa T, Wantanabe G, Sakamoto N, Iguchi A (1993): Activation of GABAA receptors in hypothalamus modulates PgF2alpha or PgE2-induced catecholamine secretion in rats. Prostaglandins 45, 111-119 https://doi.org/10.1016/0090-6980(93)90026-4

Pavord I, Holland E, Baldwin D, Tattersfield A, Knox A (1995): Effects of diuretics on allergen-induced contractions of passively sensitized human bronchi in vitro. Am. J. Respir. Crit. Care Med. 152, 1164-1169 https://doi.org/10.1164/ajrccm.152.4.7551365

Pawley AC, Flesher S, Boegman RJ, Beninger RJ, Jhamandas KH (1996): Differential action of NMDA antagonists on cholinergic neurotoxicity produced by $\mathrm{N}$-methyl-D-aspartate and quinolinic acid. Br. J. Pharmacol. 117, 1059-1064 https://doi.org/10.1111/j.1476-5381.1996.tb16697.x

Peng BG, Chen S, Lin X (2003): Aspirin selectively augmented Nmethyl-D-aspartate types of glutamate responses in cultured spiral ganglionic neurons of mice. Neurosci. Lett. 343, 21-24 https://doi.org/10.1016/S0304-3940(03)00296-9

Perkins RS, Dent G, Chung KF, Barnes PJ (1992): The effect of anion transport inhibitors and extracellular Cl-concentration on eosinophil respiratory burst activity. Biochem. Pharmacol. 43, 2480-2483 https://doi.org/10.1016/0006-2952(92)90329-H 
Planaguma A, Titos E, Lopez-Parra M, Gaya J, Pueyo G, Arroyo V, Claria J (2002): Aspirin (ASA) regulates 5-lipoxygenase activity and peroxisome proliferator- activated receptor alphamediated CINC-1 release in rat liver cells: novel actions of lipoxin A4 (LXA4) and ASA-triggered 15-epi-LXA4. FASEB J. 16, 1937-1939 https://doi.org/10.1096/fj.02-0224fje

Reinsprecht M, Pecht I, Schindler H, Romanin C (1992): Potent block of Cl- channels by antiallergic drugs. Biochem. Biophys. Res. Commun. 188, 957-963 https://doi.org/10.1016/0006-291X(92)91325-K

Salimi M, Stoger L, Liu W, Go S, Pavord I, Klenerman P, Ogg G, Xue L (2017): Cysteinyl leukotriene E4 activates human ILC2s and enhances the effect of prostaglandin D2 and epithelial cytokines. J. Allergy Clin. Immunol. 140, 1090-1100 https://doi.org/10.1016/j.jaci.2016.12.958

Seto V, Hirota C, Hirota S, Janssen LJ (2008): E-ring isoprostanes stimulate a $\mathrm{Cl}$ - conductance in airway epithelium via prostaglandin E2-selective prostanoid receptors. Am. J. Resp. Cell Biol. 38, 88-94 https://doi.org/10.1165/rcmb.2007-0117OC

Sheppard A, Hayes SH, Chen GD, Ralli M, Salvi R (2014): Review of salicylate-induced hearing loss, neurotoxicity, tinnitus and neurophysiology. Acta Otorhinolaryngol. Ital. 34, 79-93

Shirasaki T, Klee MR, Nakave T, Akaike N (1991): Differential block of bicuculline and strychnine on GABA- and glycine-induced responses in dissociated rat hippocampal pyramidal cells. Brain Res. 561, 77-83 https://doi.org/10.1016/0006-8993(91)90751-G

Sinkkonen ST, Mansikkamaki S, Moykkynen T, Luddens H, UusiOukari M, Korpi E. (2003): Receptor subtype-dependent positive and negative modulation of GABAA receptor function by niflumic acid, a non-steroidal anti-inflammatory drug. Mol. Pharmacol. 64, 753-763

https://doi.org/10.1124/mol.64.3.753

Stevens W, Buchheit K, Cahill KN (2015): Aspirin-exacerbated diseases: advances in asthma with nasal polyposis, urticaria, angioedema and anaphylaxis. Curr. Allergy Asthma Rep. 15, 69 https://doi.org/10.1007/s11882-015-0569-2

Teng CM, Chen WY, Ko WC, Ouyang CH (1987): Antiplatelet effect of butylidenepthalide. Biochim. Biophys. Acta 924, 375-382 https://doi.org/10.1016/0304-4165(87)90151-6

Thorat MA, Cuzick J (2015): Prophylactic use of aspirin: systemic review of harms and approaches to mitigation in the general population. Eur. J. Epidemiol. 30, 5-18

https://doi.org/10.1007/s10654-014-9971-7

Velazquez JR, Teran LM (2013): Aspirin-intolerant asthma: a comprehensive review of biomarkers and pathophysiology. Clin. Rev. Allergy Immunol. 45, 75-86 https://doi.org/10.1007/s12016-012-8340-0

Verriere V, Higgins G, Al-Alawi M, Costello RW, McNally P. Chiron R, Harvey BJ, Urbach V (2012): Lipoxin A4 stimulates calcium-activated chloride currents and increases airway surface liquid height in normal and cystic fibrosis airway epithelia. PLoS One 7 https://doi.org/10.1371/journal.pone.0037746

Wang YP, Wu Y, Li LY, Zheng J, Liu RG, Zhou JP, Yuan SY, Shang Y, Yao SL (2011): Aspirin-triggered lipoxin A4 attenuates LPSinduced pro-inflammatory responses by inhibiting activation of NF-KB and MAPKs in BV-2 microglial cells. J. Neuroinflam. 8, 95 https://doi.org/10.1186/1742-2094-8-95

Williams WR (2011): Relative similarity within purine nucleotides and ligand structures operating on nitric oxide synthetase, guanylyl cyclase and potassium (KATP, BKCa) channels. J. Pharm. Pharmacol. 63, 95-105 https://doi.org/10.1111/j.2042-7158.2010.01169.x

Woessner KM (2017): Update on aspirin-exacerbated respiratory disease. Curr. Allergy Asthma Rep. 17, 2 https://doi.org/10.1007/s11882-017-0673-6

Yoshida S, Amayasu H, Sakamoto H, Onuma K, Shoji T, Nakagawa H, Tajima T (1998): Cromolyn sodium prevents bronchoconstriction and urinary LTE4 excretion in aspirin-induced asthma. Ann. Allergy Asthma Immunol. 80, 171-176 https://doi.org/10.1016/S1081-1206(10)62951-1

Zhao L, Li L, Ma KT, Wang Y, Li J, Shi WY, Zhu H, Zhang ZS, Si JQ (2016): NSAIDs modulate GABA-activated currents via Ca2+activated $\mathrm{Cl}$ - channels in rat dorsal root ganglionic neurons. Exp. Thera. Med. 11, 1755-1761

Received: November 20, 2017

Final version accepted: January 17, 2018

First published online: June 29, 2018 